\title{
Surface-modified bacterial nanofibrillar PHB scaffolds for bladder tissue repair
}

\section{Zeynep Karahaliloğlu, Murat Demirbilek, Mesut Şam, Necdet Sağlam, Alpay Koray Mızrak \& Emir Baki Denkbaş}

To cite this article: Zeynep Karahaliloğlu, Murat Demirbilek, Mesut Șam, Necdet Sağlam, Alpay Koray Mızrak \& Emir Baki Denkbaș (2016) Surface-modified bacterial nanofibrillar PHB scaffolds for bladder tissue repair, Artificial Cells, Nanomedicine, and Biotechnology, 44:1, 74-82, DOI: 10.3109/21691401.2014.913053

To link to this article: https://doi.org/10.3109/21691401.2014.913053

\section{Published online: 27 May 2014.}

\section{Submit your article to this journal $\widetilde{ }$}

II Article views: 358

Q View related articles $\sqsubset$

View Crossmark data $־$

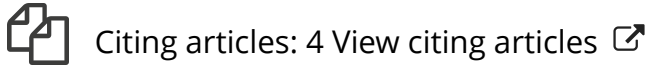




\title{
Surface-modified bacterial nanofibrillar PHB scaffolds for bladder tissue repair
}

\author{
Zeynep Karahaliloğlu ${ }^{1}$, Murat Demirbilek ${ }^{1}$, Mesut Şam², Necdet Sağlam ${ }^{1}$, Alpay Koray Mızrak³ \& \\ Emir Baki Denkbaş 1,4 \\ ${ }^{1}$ Division of Nanotechnology and Nanomedicine, Hacettepe University, Beytepe, Ankara, Turkey, ${ }^{2}$ Department of Biology, \\ Aksaray University, Aksaray, Turkey, ${ }^{3}$ UNAM, Institute of Materials Science and Nanotechnology, Bilkent University, Bilkent, \\ Ankara, Turkey, and ${ }^{4}$ Division of Biochemistry, Department of Chemistry, Hacettepe University, Beytepe, Ankara, Turkey
}

\begin{abstract}
The aim of the study is in vitro investigation of the feasibility of surface-modified bacterial nanofibrous poly [(R)-3hydroxybutyrate] (PHB) graft for bladder reconstruction. In this study, the surface of electrospun bacterial PHB was modified with PEG- or EDA via radio frequency glow discharge method. After plasma modification, contact angle of EDAmodified PHB scaffolds decreased from $110 \pm 1.50$ to $23 \pm 0.5$ degree. Interestingly, less calcium oxalate stone deposition was observed on modified PHB scaffolds compared to that of non-modified group. Results of this study show that surfacemodified scaffolds not only inhibited calcium oxalate growth but also enhanced the uroepithelial cell viability and proliferation.
\end{abstract}

Keywords: bladder reconstruction, calcium oxalate stones, nanotexture, poly [(R)-3-hydroxybutyrate] $(\mathrm{PHB})$, tissue engineering

\section{Introduction}

In the world, about 400 million people complained about cancer or other bladder disease (Atala 2000). Treatments for bladder cancer are partial resection of the bladder wall, immunotherapy, chemotherapy, and radiation (Pattison et al. 2005). In recent years, enterocystoplasty has become a frequently used technique amongst aforementioned bladder cancer treatments. Enterocystoplasty is a bladder reconstruction procedure using natural tissue. In this technique, a portion of intestine is placed on the bladder mucosa. This surgical reconstruction was used to increase the bladder capacity and reduce the amount of pressure on the bladder wall. But, enterocystoplasty has many disadvantages such as transplant area perforation, infections, metabolic diseases, and excessive mucus production (Eberli 2010). Based on these problems, tissue engineering has been used for bladder reconstruction as a promising approach for several years. Tissue engineering is a multidisciplinary field involving biology, medicine, and engineering for replacing compromised or lost tissue and organ functions (Langer and Vacanti 1993, Persidis 1999). Scaffolds prepared via tissue engineering approach plays important role for bladder disease treatment, which have adjustable properties such as mechanical, elasticity, and biocompatibility. Polymeric biomaterials in the bladder replacement have been promising repair materials. In the bladder reconstruction as biologically derived materials used bladder acellular matrix, small intestinal submucosa (Zhang et al. 2000, 2004), as synthetic polymeric materials used such as poly(glycolic acid) (PGA), Poly(lactic-co-glycolic acid), polyL-lactic acid, poly- $\varepsilon$-caprolactone and polyurethane (Mooney et al. 1996, Mikos et al. 1994). Poly(hydroxyalkanoate)s [P(HA) $\mathrm{s}$, a family of microbial-derived polyesters, produced by a variety of bacteria and have been widely used for biomedical applications (Chen and Wu 2005, Lenz and Marchessault 2005). Among them, in the last decades, PHB was used as attractive material in tissue engineering application because of its compatibility in contact with tissue and blood and nontoxic properties (Gogolewski et al. 1993, Clarotti et al. 1992). Further, its degradation product, 3-hydroxybutyric acid, is found naturally in human blood (Lee 1996). Recently, a wide variety of research studies is based on the behavior of bladder cells on the PHAderived scaffolds. Renard et al. (2011) investigated the effect of chemical structure of PHAs modified with poly(ethyleneglycol) PEG on the adhesion and proliferation of human bladder carcinoma RT112 cells. On other hand, Garcia et al. found that poly(3-hydroxybutyrate-co-3-hydroxyvalerate) $[\mathrm{P}(\mathrm{HB}-\mathrm{co}-\mathrm{HV})]$ functionalized with a laminin-derived YIGSR sequence clearly enhanced the adhesion of urothelial cells. (García-García et al. 2012). These report showed that PHB is a potential biomaterial to be used in bladder tissue engineering applications and there are limited studies related to its use in this field.

Correspondence: Emir Baki Denkbaş, Department of Chemistry, Hacettepe University, 06800 Beytepe, Ankara, Turkey. Tel: + 903122977992. Fax: + 90312299 2163. E-mail: denkbas@hacettepe.edu.tr

(Received 17 February 2014; revised 3 April 2014; accepted 4 April 2014) 
Surface properties of medically used biomaterials have a considerable influence on the acceleration of tissue regeneration (Mooney et al. 1996). In previous studies, the effect of nanoscale surface features created through chemical etching compared with conventional form had examined on the cell density, inhibition of calcium stone formation, and bladder tissue regeneration capability (Chun et al. 2009). The published results demonstrated that nanotextured surfaces increase the adsorption and bioactivities of adhesive proteins such as fibronectin and vitronectin (Khang et al. 2007, Miller et al. 2005). The nanoscale rough polymeric materials promote the cellular adhesion, proliferation, and extracellular matrix synthesis in bone, cartilage, vascular, and bladder tissue (Ratner et al. 2004). In addition to that, it has been shown that these materials inhibited calcium oxalate stone formation owing to surface properties (Chun et al. 2009, 2010). Electrospinning, which is a frequently used nanofabrication system in tissue engineering applications, can mimic the collagen fibers on the native extracellular matrix (Li et al. 2002). The previous studies reported that nanofibrillar scaffolds showed better performance related to the cytoskeletal alignment of adherent cells and cellular phenotype expression compared to conventional microfiber structures (Harrington et al. 2008). In another study, Harrington and colleagues have modified the surface of fiberbonded poly(glycolic acid) (PGA) scaffolds using branched peptide-amphiphile(b-PA)molecules containing cell-adhesive RGDS. Primary human bladder smooth muscle cells showed greater initial adhesion to b-PA-modified scaffolds than to uncoated PGA scaffolds (Harrington et al. 2006). Further, Baker et al. also demonstrated that argon plasma of electrospun polystyrene nanofiber scaffolds significantly enhanced smooth muscle cell attachment. Electrospun polymer nanofibers have been widely used in bladder tissue engineering owing to theirs tendency to mimic nanostructured bladder ECM (Baker et al. 2006). The data suggest that electrospinning may be useful process for promoting of mouse bladder epithelial cells.

For these reasons, the purpose of this study was to produce surface properties-enhanced electrospun bacterial PHB scaffolds which could be used for partial reconstruction of the bladder. We first characterized synthesized PHB using Differential Scanning Calorimetry (DSC) and then viscosimetric molecular weight was determined. In a first stage, the surface of nanofibrous PHB scaffolds were functionalized with different charged polymers such as EDA and PEG. These modified scaffolds were characterized using scanning electron microscopy (SEM), contact angle measurement, and $\mathrm{X}$-ray photoelectron spectroscopy (XPS) to assess the surface topography, wettability, and surface chemistry, respectively. Using mouse bladder epithelial cells, the effect of plasma treatment on uroepithelial cell attachment and proliferation, and the stone formation were determined using a modified 3-[4,5-dimethyl(thiazol-2yl)-3,5-diphery] tetrazolium bromide (MTT) assay and Alizarin Red-S staining, respectively.

\section{Materials and methods}

\section{Materials}

Poly [(R)-3-hydroxybutyrate], (PHB) and ethylenediamine (EDA) were obtained from Fluka (Switzerland). The average molecular weight (Mw) for used commercial PHB to compare with our synthesized bacterial PHB was 540,000 g/mol. Chloroform was used as a solvent and obtained from Sigma (USA). Polyethylene glycol, PEG (Acros, Belgium, Mw = $300 \mathrm{Da}$ ), and EDA were used for the modification of PHB scaffolds.

3-(4,5-Dimethylthiazol-2-yl)-2,5-Diphenyl tetrazolium bromide (MTT) was purchased from Aldrich (USA). Mouse urinary bladder cells were maintained in Dulbecco Modified Eagle's Medium (DMEM)/Ham's F10 (1:1) supplemented with fetal bovine serum (FBS) and 1\% penicillin/streptomycin (Biological Industries, Israel), $10 \mathrm{mg} / \mathrm{ml}$ insulin (Sigma), $5 \mathrm{mg} / \mathrm{ml}$ transferrin (Gibco/BRL, France), $5 \mathrm{ng} / \mathrm{ml}$ selenite F (Gibco/ BRL, France), $10 \mathrm{mM}$ HEPES, and $50 \mathrm{nM}$ hydrocortisone.

\section{Bacterial PHB production and characterization}

Alcaligenes eutrophus was used for bacterial PHB production as reported in our previous study. (Karahaliloğlu et al. 2012). Cells were first grown in $250 \mathrm{ml}$ containing $50 \mathrm{ml}$ of nitrogen-rich medium for $24 \mathrm{~h}$, which contains $10 \mathrm{~g} / \mathrm{l}$ glucose, $2 \mathrm{~g} / \mathrm{l}$ yeast extract, $2 \mathrm{~g} / \mathrm{l}$ pepton, $1 \mathrm{~g} / 1 \mathrm{~K}_{2} \mathrm{HPO}_{4}, 1 \mathrm{~g} / 1 \mathrm{KH}_{2} \mathrm{PO}_{4}$, $1 \mathrm{~g} / \mathrm{l}\left(\mathrm{NH}_{4}\right) \mathrm{SO}_{4}$, and $0.05 \mathrm{~g} / \mathrm{l} \mathrm{MgSO}_{4} .7 \mathrm{H}_{2} \mathrm{O}$. Bacteria were collected via centrifugation and suspended in the medium. The medium contains (per liter): sucrose $20 \mathrm{~g}, \mathrm{KH}_{2} \mathrm{PO}_{4}$ $1.5 \mathrm{~g}, \mathrm{Na}_{2} \mathrm{PO}_{4} 3 \mathrm{~g}, \mathrm{MgSO}_{4} 0.2 \mathrm{~g}, \mathrm{CaCl}_{2} 2 \mathrm{H}_{2} \mathrm{O} 0.01 \mathrm{~g}$, and $1 \mathrm{ml}$ of trace element solution. Trace element solution contains (per liter): $\mathrm{FeSO}_{4} .7 \mathrm{H}_{2} \mathrm{O} 2 \mathrm{~g}, \mathrm{H}_{3} \mathrm{PO}_{4} 0.3 \mathrm{~g}, \mathrm{CoCl}_{2} 6 \mathrm{H}_{2} \mathrm{O} 0.2 \mathrm{~g}$, $\mathrm{ZnSO}_{4} 7 \mathrm{H}_{2} \mathrm{O} 0.03, \mathrm{MnCl}_{2} \cdot 4 \mathrm{H}_{2} \mathrm{O} 0.03 \mathrm{~g},\left(\mathrm{NH}_{4}\right) 6 \mathrm{Mo}_{7} \mathrm{O}_{24} 4 \mathrm{H}_{2} \mathrm{O}$ $0.03 \mathrm{~g}$, $\mathrm{NiSO}_{4} 7 \mathrm{H}_{2} \mathrm{O} 0.03 \mathrm{~g}$, and $\mathrm{CuSO}_{4} 5 \mathrm{H}_{2} \mathrm{O} 0.01 \mathrm{~g}$. The bacteria were cultivated at $150 \mathrm{rpm}$ and $30^{\circ} \mathrm{C}$ for $48 \mathrm{~h}$. After cultivation, cell broth was centrifuged at $4,000 \times$ g for $10 \mathrm{~min}$, washed twice with distilled water, and then stored at $-80^{\circ} \mathrm{C}$ for overnight. Bacterial PHB containing biomass was suspended in $5 \mathrm{ml}$ of sodium-hypochlorite solution for $24 \mathrm{~h} 37^{\circ} \mathrm{C}$. The solution was centrifuged twice and supernatant was removed. Bacterial PHB containing cell debris was washed with distilled water and the biomass was mixed with $5 \mathrm{ml}$ chloroform for $1 \mathrm{~h}$ at $37^{\circ} \mathrm{C}$. The clear polymer solution was recovered via centrifugation to remove the majority of the non-PHB cell material.

As can be seen in previous published work, bacterial PHB was characterized using Nuclear Magnetic Resonance and Fourier Transform Infrared and obtained high purity polymer. In this study, the thermal properties of synthesized polymer were characterized using a Mettler Toledo DSC-1. DSC analysis was performed under nitrogen atmosphere from 25 to $220^{\circ} \mathrm{C}$ at a heating rate of $10^{\circ} \mathrm{C} / \mathrm{min}$. The crystallinity percent of bacterial PHB was calculated from DSC results using the following equation.

$$
\mathrm{X}_{\mathrm{c}}(\%)=\Delta \mathrm{H} 100 / \Delta \mathrm{H}_{0}
$$

where $\Delta \mathrm{H}_{0}$ described melting enthalpy of $100 \%$ crystalline PHB that the value assumed to be $146 \mathrm{~J} / \mathrm{g}$ in the literature (Gogolewski et al. 1993, Li et al. 2003, Barham et al. 1984). $\Delta \mathrm{H}$ is the melting enthalpy of the sample.

Viscosimetric molecular weight of bacterial $\mathrm{PHB}$ was measured using Ubbelohde capillary viscometer at $25^{\circ} \mathrm{C}$ in a thermostat bath. Firstly, PHB was dissolved in chloroform at different concentrations and efflux times of the polymers were measured using the serial dilution technique. The rela- 
tive viscosity $\left(\eta_{r}\right)$ of polymer was calculated using of $\eta_{r=} t / t_{0}$ equation according to the flow time of polymer and solvent. Specific viscosity was calculated using following equation

$$
\eta_{\mathrm{sp}}=\eta_{\mathrm{r}}-1=\left(\mathrm{t}-\mathrm{t}_{0}\right) / \mathrm{t}_{0}(\text { Cincu et al. 2000) }
$$

From the specific viscosity value $\left(\eta_{\mathrm{sp}}\right)$ of polymer intrinsic viscosity was calculated.

$$
\eta_{\mathrm{sp}}=[\eta] \mathrm{c}+\mathrm{k}[\eta]^{2} \mathrm{c}^{2}
$$

Viscosimetric molecular weight (Mv) of bacterial PHB polymer was calculated directly according to MarkHouwink-Sakurada equation, where $\mathrm{K}$ and $\alpha$ are constants.

$$
[\eta]=\mathrm{KMv} \alpha(\text { Ichikawa et al. 1995) }
$$

\section{Urinary bladder matrix preparation using electrospinning}

Five percent weight of PHB solutions was prepared by dissolving in $\mathrm{CHCl}_{3} /$ ethanol solutions (3:1 v/v) overnight. In the study, a high-voltage power supply (Spellman CZE1000R) was used for the production of nanofiber. Systems parameters are $5 \%$ polymer concentration, $17 \mathrm{kV}$ voltages, the distance between the tip of the syringe and collector is $15 \mathrm{~cm}$, and $2 \mathrm{ml} / \mathrm{h}$ flow rate.

\section{Plasma modifications of bacterial PHB nanofibrillar scaffolds} PHB scaffolds were modified by plasma for alteration of the scaffold surface chemistry, that is, to increase the cell attachment and growth. Plasma was processed in a stainless steel parallel-plate plasma reactor using PEG and EDA monomers. Plasma modification system (Vacuum, Praha) was equipped with radio frequency $(\mathrm{RF}, 13.56 \mathrm{MHz})$ glow discharges generator and it was attached to a vacuum pump for maintaining the vacuum inside the chamber. Before the plasma process, $\mathrm{PHB}$ scaffolds were cut into a size of $1 \times 1 \mathrm{~cm}$ and positioned on the grounded electrode with exposing the sample to plasma glow. As a first, argon gas was passed through the reactor at $0.1 \mathrm{~m}$ bar pressure in order to remove reactive species like oxygen and nitrogen. Then, the reactor was fed with PEG and EDA, respectively, and the glow discharge initiated at power of $35 \mathrm{~W}$ for $20 \mathrm{~min}$. The argon gas was passed through the chamber again to sweep away any gaseous residue. The scaffolds were kept in vacuum for $10 \mathrm{~min}$ for the stabilization of modification.

\section{Contact angle measurement}

The wettability of modified and non-modified bacterial PHB surfaces was evaluated using contact angle measurements (DSA100, KRUSS, Germany). The samples were cut into $0.5 \mathrm{~cm} \times 0.5 \mathrm{~cm}$ (length $\times$ width) for the analysis. Deionized water was dropped on the PHB samples through the micro syringe at room temperature. Average static contact angles and its standard deviation of non-modified and modified PHB scaffolds were calculated by obtaining five measurements from different parts of the samples.

\section{In-vitro degradation}

Samples were cut into small pieces $0.5 \mathrm{~cm} \times 0.5 \mathrm{~cm}$ and weighed $\left(\mathrm{W}_{0}\right)$. The mass loss rate of the sample was determined by immersing into phosphate buffer saline (PBS $\mathrm{pH}$ : 7.4). The samples were placed in $5 \mathrm{~mL}$ of PBS solutions ( $\mathrm{pH} 7.4$ ) and incubated for $1,2,3,4$, and 5 weeks at $37^{\circ} \mathrm{C}$. Every week samples were removed from solutions, washed with distilled water, lyophilized for $3 \mathrm{~h}$ and weighed (Wt). PBS solution was replaced with new solution each week.

$$
\operatorname{Degradation}(\%)=\left[\left(\mathrm{W}-\mathrm{W}_{\mathrm{t}}\right) / \mathrm{W}_{0}\right] \times 100
$$

\section{Calcium stone synthesis}

For the calcium stone synthesis, $0.5 \mathrm{~g} \mathrm{CaCl}_{2}$ was placed in a $250 \mathrm{ml}$ dry beaker and $10 \mathrm{ml}$ of $6 \mathrm{M} \mathrm{HCl}$ was added slowly to this solution. The erlenmeyer was covered with a watch glass. After the dissolution completed, the solution was diluted with $150 \mathrm{~mL}$ deionized water. This aqueous solution was heated to boil in the fume hood. $5 \mathrm{~g}$ ammonium oxalate was dissolved in $50 \mathrm{ml}$ water and heated to dissolve the salt completely. Ammonium oxalate solutions were added to the hot calcium chloride solutions. A few drops of $\mathrm{NH}_{3}$ were added until a precipitation occurs. The precipitate was removed with a filter paper and dried.

\section{Calcium deposition on the scaffold}

Calcium deposition on the PHB scaffolds was examined by Alizarin Red-S staining. PHB scaffolds were cut into $0.5 \times 0.5$ $\mathrm{cm}$ in square shape. $0.013 \mathrm{~g}$ of synthesized oxalate was dispersed in $10 \mathrm{ml}$ of distilled water. PHB scaffolds were placed in $1 \mathrm{ml}$ of oxalate solutions on 1st, 3rd, 5th and 7th days. At the end of each day, the scaffolds were removed and fixed with cold methanol solutions for $10 \mathrm{~min}$. All samples were washed twice with distilled water and immersed in $200 \mu \mathrm{l}$ Alizarin Red-S solutions (in a mixture of ammonium hydroxide/water; 1:100, pH: 4.1-4.3) for 3 min. For the destaining, cetylpyridinium chloride monohydrate solution, which was prepared at $10 \%$ concentration in $10 \mathrm{mM}$ sodium phosphate at room temperature, was used. These samples were placed in this solution for $15 \mathrm{~min}$ and spectrophotometrically read at $570 \mathrm{~nm}$.

\section{XPS analysis}

XPS (Thermo Scientific K-Alpha, USA) was used to analyze the surface chemistry of bacterial PHB scaffolds before and after calcium oxalate treatment. Each of the $0.5 \times 0.5 \mathrm{~cm}-$ sized samples was placed in tubes containing $0.13 \%$ calcium oxalate solution. Calcium amount on the scaffolds was monitored after 1, 3, 5, and 7 days. The scaffolds were irradiated with a monochromatized Al Ka X-ray source (1486,6 eV). The pass energy of the analyzer was $50 \mathrm{eV}$ for high-resolution core level spectra and the beam spot was $400 \mu \mathrm{m}$. Curve fitting of the spectra was performed with the Thermo Avantage v4.41 Software. A Shirley-type correction was applied to the background under all fitted peaks.

\section{In-vitro cell proliferation}

In-vitro cell proliferation on the PHB scaffolds was observed using colorimetric MTT (a yellow tetrazole) assay. Mouse urinary bladder cell line (Foot and Mouth Diseases Institute, Ankara-Turkey) were cultured in a mixture of DMEM and Ham's F10 (1:1) supplemented with 10\% FBS and 1\% penicillin/streptomycin, $10 \mathrm{mg} / \mathrm{ml}$ insulin, $5 \mathrm{mg} / \mathrm{ml}$ transferrin, 5 


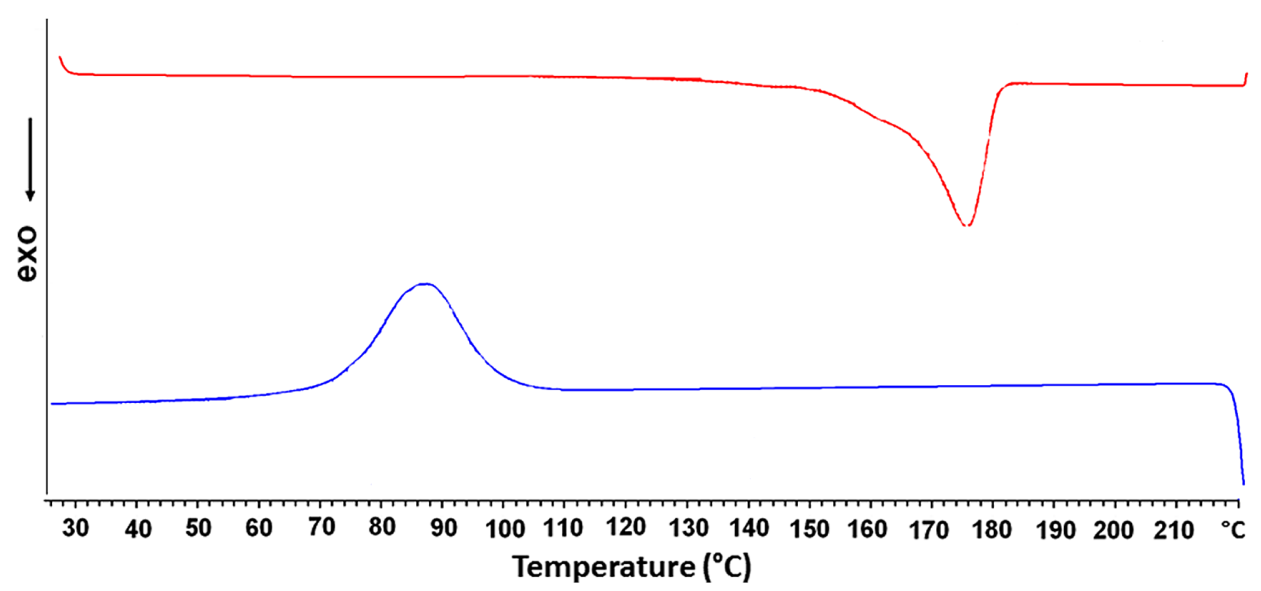

Figure 1. Differential scanning calorimetry thermogram of bacterial PHB. Bacterial PHB with a crystallinity ratio of $59.7 \%$ and molecular weight of $82.500 \mathrm{~g} / \mathrm{mol}$ is obtained from A. eutrophus strain.

$\mathrm{ng} / \mathrm{ml}$ selenite F, $10 \mathrm{mM}$ HEPES, $50 \mathrm{nM}$ hydrocortisone. PHB scaffolds $(1 \times 1 \mathrm{~cm})$ were placed in a 24 -well culture plate. The scaffolds were sterilized by immersion in $70 \%$ EtOH for 5 min, and then washed twice with culture medium. After the reach to $80 \%$ confluence, the uroepithelial cells were detached by trypsin-EDTA and counted with hemocytometer. $1 \times 10^{3}$ cells were pipetted on the scaffolds into a 96-well plate. The cells were incubated at $37^{\circ} \mathrm{C}$ in a $5 \% \mathrm{CO}_{2}$ incubator and monitored during $1,3,5$, and 7 days. The culture medium was changed daily. At the end of each day, the PHB samples were placed to another culture plate, $200 \mu$ MTT reagent was added to the samples. After $4 \mathrm{~h}$ incubation in dark, the MTT solution was removed and acidic isopropyl alcohol of $200 \mu \mathrm{l}$ was added to 24-well plate for dissolving of formazan crystals. After remove of samples, the optical density of the solutions in 96-well plate was measured using Microplate-Reader at a wavelength of $570 \mathrm{~nm}$.

Uroepithelial cell morphology on the non-modified and modified PHB scaffolds was studied using SEM. The scaffolds were fixed with $2.5 \%$ glutaraldehyde for 1

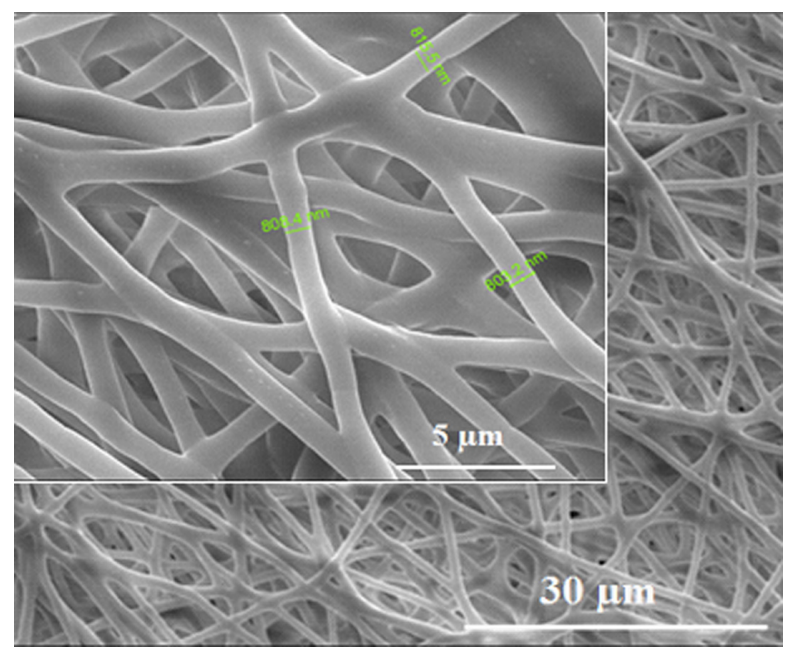

Figure 2. SEM images of the electrospun bacterial PHB nanofiber scaffolds. The insets show higher magnification images of the surfaces. Bacterial PHB nanofiber scaffolds with a diameter of $700 \mathrm{~nm}$ to $800 \mathrm{~nm}$ are obtained. Scale bars are 30 and $5 \mu \mathrm{m}$. $\mathrm{h}$ and immersed in a series of ethanol solutions $(25,50$, 75,90 and $100 \%$ ), respectively, then the samples were dehydrated with hexamethyldisilazane. After drying, the samples were coated with gold/palladium mixture for SEM examination.

\section{Statistical analysis}

All data values were studied least as in triplicate and presented as mean \pm standard deviation. Statistical analyses were carried out using PASW Statistics version 18. Significant differences between groups were performed by Scheffe's test and $p<0.05$ was considered as statistically significant.

\section{Results}

\section{Characterization of bacterial PHB}

The DSC thermogram of the bacterial PHB is presented in Figure 1. Bacterial PHB showed a crystallization peak

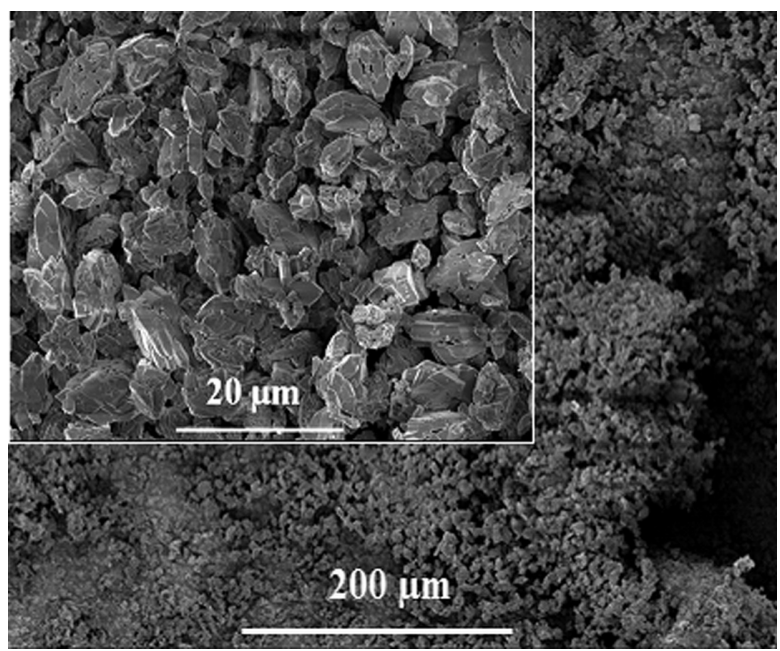

Figure 3. SEM images of synthesized calcium oxalate stones. The insets show higher magnification images of the synthesized calcium oxalate stones. Calcium oxalate stones show crystal morphology. Scale bars are 20 and $200 \mu \mathrm{m}$. 


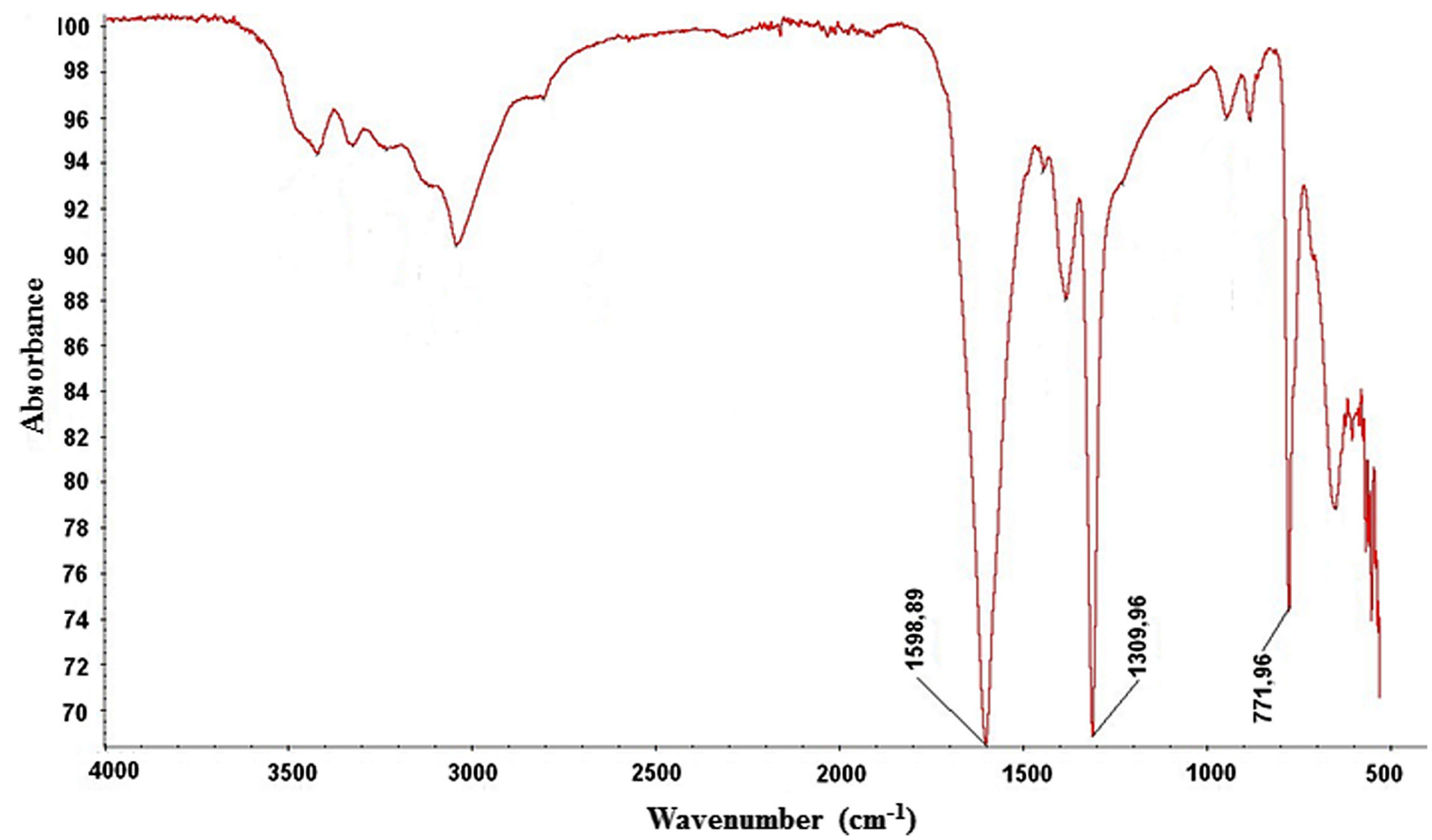

Figure 4. FTIR spectrum of the synthetic calcium oxalate stones. According to the obtained FTIR-spectra, the synthetic calcium oxalate stones showed all of the typical bands.

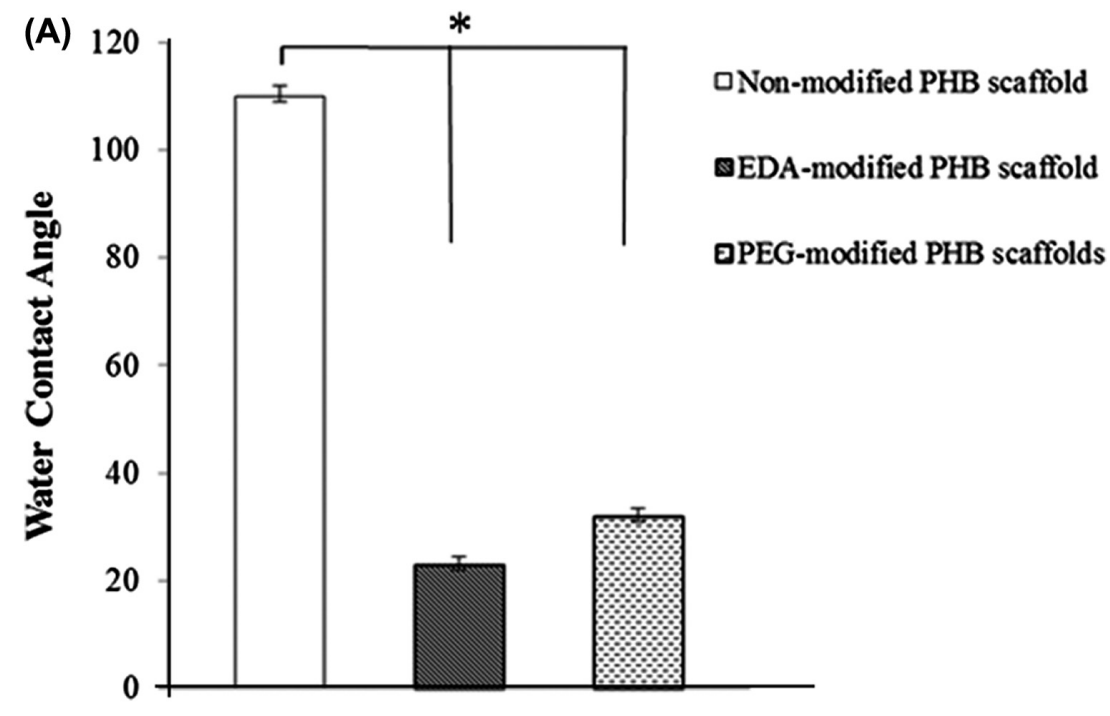

(B)

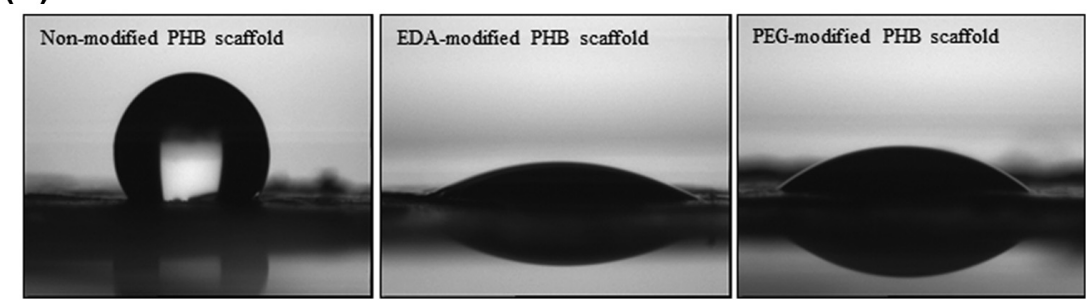

Figure 5. (A) Comparison of water contact angle values for the non-modified and modified PHB scaffolds. (B) Images of the water contact angles for the non-modified, EDA- and PEG-modified scaffolds. EDA and PEG plasma treatment enhanced the wettability of bacterial nanofibrillar PHB scaffolds. Values are mean $\pm \mathrm{EM} ; n=5 ;{ }^{*} p<0.005$ compared to the non-modified PHB scaffold. 


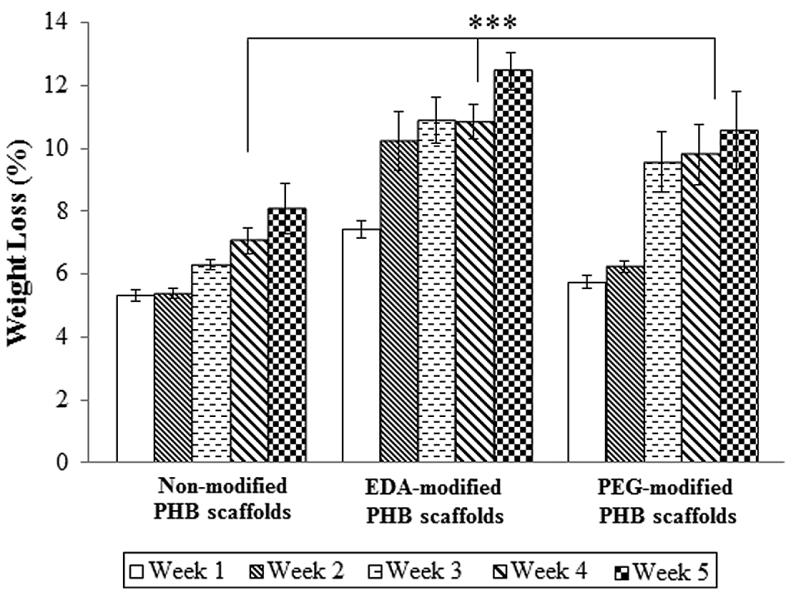

Figure 6. In-vitro degradation of non-modified and modified PHB scaffolds in PBS solution. There is no statistical difference related to degradation rate between groups. Values are mean $\pm \mathrm{EM} ; n=3$; statistical significance are marked as $* * * p>0.05$.

around $85.97^{\circ} \mathrm{C}$ and the corresponding melting temperature was $173.80^{\circ} \mathrm{C}$. In concordance with Erceg et al. (2005), the melting temperature of PHB was obtained around $170-180^{\circ} \mathrm{C}$. However the percentage of the crystallinity was $62 \%$ for commercial PHB (Chaijamrus and Udpuay 2008). In the presented study, the enthalpy of fusion was $87.17 \mathrm{~J} / \mathrm{g}$ and crystallinity ratio of bacterial PHB was calculated as 59.7\%. Thermal properties of bacterial PHB is compatible with the results of the literature. Average molecular weight of bacterial PHB was determined using the viscosimetric measurement and obtained as $\mathrm{Mv}=82,500 \mathrm{~g} / \mathrm{mol}$.

\section{Characterization of bacterial PHB scaffolds}

Nanofibrillar bacterial PHB scaffolds were produced by electrospinning, in order to investigate the effect of nanoscaled surface properties on the calcium oxalate deposition and cell adhesion. Three dimensional, porous, nanofibrillar bacterial PHB scaffolds were successfully created using electrospinning method. A porous, non-bead randomly fibrillar structure was obtained, which had an average fiber diameter 700-800 $\mathrm{nm}$ (Figure 2). The surface modification of the samples with EDA and PEG was performed using radio frequency glow discharge. In our previous work, the surface analysis results of PHB scaffolds have been presented and a successfully surface treatment was observed according to obtained results.

Synthesis and characterizations of calcium oxalate stones Structure of synthetic calcium oxalate stones was evaluated with SEM. As can be seen in Figure 3, calcium stones indicated typical crystal morphology under electron microscope (Ouyang and Deng 2003). Spectroscopic analysis of calcium oxalate formation was obtained using FT-IR spectroscopy. Figure 4 shows the IR spectrum of the calcium oxalate stones. Typical bands for calcium oxalate stones were the strong bands around 778.53 ( $\mathrm{C}=\mathrm{O}$ asymmetrical stretching), 1314.93 (C-C symmetrical stretching), and $1604.64(\mathrm{OC}=\mathrm{O}$ asymmetrical stretching (Channa et al. 2007, Silverstein et al. 2005). In the presented study, peaks were obtained at $771.96 \mathrm{~cm}^{-1}, 1309.96$ $\mathrm{cm}^{-1}$, and $1598.89 \mathrm{~cm}^{-1}$. These values are in good agreement with the IR-spectrum for calcium stones in the literature.

\section{Contact angle measurements}

Contact angle measurements of non-modified and modified samples were conducted to confirm surface functionalization (Figure 5A). Initially, non-modified PHB nanofibrillar scaffold indicated a contact angle of $110.5 \pm 1.50$ that is consistent with previous reports (Sombatmankhong et al. 2007). Hydrophilicity increased dramatically after EDA or PEG modifications. The dramatic reduction in contact angle attributed to the success of plasma treatment. Especially, EDA-modified nanofibrillar scaffolds showed a much better wettability compared to PEG-modified. The decrease from 110.5 \pm 1.50 to $23 \pm 0.5$ degree can be attributed to formation of amine $\left(-\mathrm{NH}_{2}\right)$ generated on the surface by the plasma treatment.

\section{Scaffold degradation in-vitro}

In vitro degradation of modified and non-modified electrospun PHB scaffold was investigated in PBS solution at $37^{\circ} \mathrm{C}$ for a period of 5 weeks. Figure 6 shows the mass changes of non-modified and modified bacterial PHB scaffolds. The mass loss of the non-modified PHB scaffolds was approximately $8.08 \%$ after 5 weeks while the EDA- and PEG-modified scaffolds show degradation rate of 12.4 and $10.5 \%$ at the end of Day 5. After 5-day degradation in PBS, data showed no statistically significant difference in related to degradation rate between non-modified and modified PHB scaffolds $(p>0.05)$. Because of theirs degradation properties, the modified PHB scaffold is expected to have great potential applications in medical treatment of bladder failure.

\section{Calcium oxalate deposition of the scaffolds}

Alizarin-red staining was used to confirm the amounts of deposited calcium oxalate on the scaffolds. The

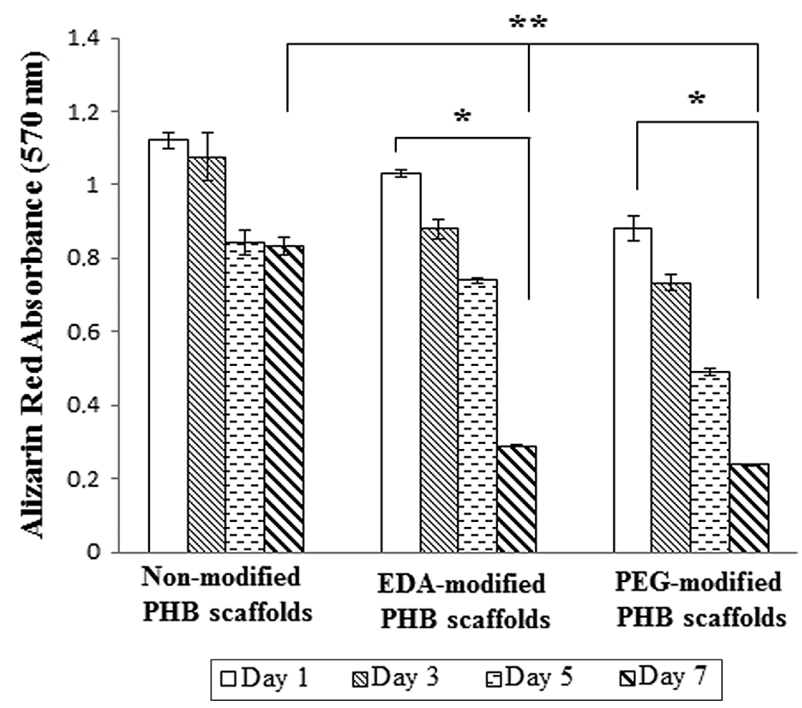

Figure 7. Amounts of deposited calcium on the non-modified, EDAand PEG-modified nanofibrillar scaffolds. Calcium oxalate deposition decreased on EDA- and PEG-modified PHB scaffolds. Values are mean $\pm \mathrm{EM} ; n=3$; statistical significance are marked as $* p<0.005$, $* * p<0.05$. 
Table I. Atomic percentages of $\mathrm{C}, \mathrm{O}, \mathrm{N}$ and Ca elements on the non-modified and modified scaffolds. Calcium oxalate deposition decreased on EDA- and PEG-modified PHB scaffolds.

\begin{tabular}{|c|c|c|c|c|c|}
\hline & $\begin{array}{c}\text { Atomic } \\
\text { percent } \\
(\%)\end{array}$ & Day 1 & Day 3 & Day 5 & Day 7 \\
\hline \multirow[t]{3}{*}{ Non-modified PHB scaffolds } & C & 68.24 & 69.71 & 69.38 & 68.5 \\
\hline & $\mathrm{O}$ & 29.12 & 27.67 & 27.39 & 28.33 \\
\hline & $\mathrm{Ca}$ & 1.56 & 0.81 & 0.79 & 0.65 \\
\hline \multirow[t]{4}{*}{ EDA-modified PHB scaffolds } & C & 68.64 & 70.59 & 70.91 & 70.04 \\
\hline & $\mathrm{O}$ & 24.22 & 18.13 & 19.53 & 21.40 \\
\hline & $\mathrm{N}$ & 6.02 & 10.58 & 8.60 & 8.44 \\
\hline & $\mathrm{Ca}$ & 1.12 & 0.70 & 0.96 & 0.21 \\
\hline \multirow[t]{3}{*}{ PEG-modified PHB scaffolds } & C & 66.69 & 66.88 & 67.84 & 67.34 \\
\hline & $\mathrm{O}$ & 28.99 & 28.54 & 27.01 & 29.46 \\
\hline & $\mathrm{Ca}$ & 0.87 & 0.56 & 0.34 & 0.11 \\
\hline
\end{tabular}

absorbance of calcium in all groups increased along with the initial concentration, especially in the modified groups. As shown in Figure 7, calcium amount on the non-modified scaffolds is higher than to modified group (EDA or PEG) during assay period. At 5th and 7th days, especially at the 7 th day, the deposited oxalate amount on the EDA- and PEG-modified group decreases. Zhang et al. found that double-hydrophilic block copolymer, poly(ethyleneglycol)-block-poly(methacrylic acid) (PEG-$b$-PMAA) changes the morphology of the calcium oxalate dihydrate crystals (Zhang et al. 2002). Further, it has been reported that the molecular weight of polyethylene glycol is mainly decisive on the inhibition performance of the calcium oxalate crystals due to charge and hydrophilic effects and the smaller molecular weight of polyethylene glycol inhibit calcium oxalate crystals more stronger (Deng 2007). In addition to that, proteins are known to act as inhibitors of crystal growth and nucleation (Pathak et al. 2011). Recent studies shown that the inhibition effect of amino acids on crystallization increased with increasing of basic $-\mathrm{NH}_{2}$ groups or presence of $-\mathrm{OH}$ groups (Yehia et al. 2012). The present study suggest that calcium oxalate crystals are inhibit through $-\mathrm{NH}_{2}$ or $-\mathrm{OH}$ groups generated after plasma treatment. Accordingly, the growth of calcium stones crystals was highly affected by the PEG and EDA modifications.

After plasma modification and calcium oxalate treatment, surface chemical composition was determined using XPS analysis. The elemental composition and atomic percent of the scaffolds are summarized in Table I. As Alizarinred staining test results, XPS results shows that EDA- or
PEG-modified scaffolds exhibit better performance than non-modified scaffolds in terms of calcium oxalate inhibition. In addition to this, amine group existence on the EDAmodified PHB scaffolds and a slight increase in carbon concentration as well as in oxygen concentration on the PEG-modified scaffolds demonstrate the success of plasma modification.

Additionally, the surface of non-modified and modified bacterial PHB scaffolds was investigated after 7 days of calcium oxalate deposition. Figure 8 shows SEM micrograph of samples. Oxalate crystals grown on the non-modifed scaffolds are relatively visible. PEG- or EDA-modified scaffolds exhibit less stone deposition in comparison to nonmodified scaffolds.

\section{Cell proliferation}

Cell viability on the scaffolds was determined using MTT mitochondrial activity assay and the results are shown in Figure 9. Mouse urinary bladder cells were seeded onto the nanoscaffolds. Adhesion and long-term cell growth experiments were performed for $1,5,7$, and 10 days. The cell proliferation increased with culture time on both non-modified and plasma-modified scaffolds. In comparison with nonmodified group, EDA- or PEG-modified nanofibrillar structure showed much more cell spreading and cell proliferation, especially EDA-modified PHB scaffolds. At Day 10, cell numbers on the EDA- and PEG-modified scaffolds were significantly greater than non-modified $(p<0.005)$. Recent reports in the literature suggest that plasma treatment processed on the surface enhanced cellular adhesion and spreading (Demirbilek et al. 2011, Karahaliloğlu et al. 2012).

The cell morphology and distribution on both non-modified and plasma modified scaffolds were examined using SEM. After 7-day culture, cell images are obtained and shown in Figure 10. The images show that cells infiltrated into electrospun PHB matrix and integrated with surrounding fibers. Especially, on the EDA- and PEG-modified scaffolds can be realized widely distribution of urinary bladder cells on the PHB scaffolds, extended of cells along the fibers and generation of a complex network with surrounding cells.

\section{Discussion}

It is well known that nanofibrous scaffolds have many advantages for tissue engineering applications. Nano-
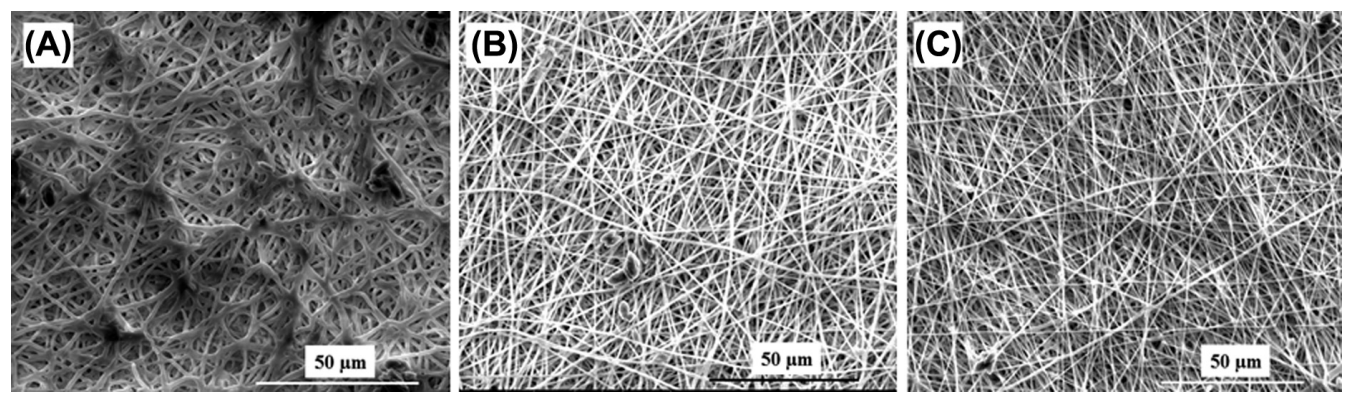

Figure 8. Calcium oxalate deposition on (A) non-modified, (B) EDA-modified and (C) PEG-modified nanofibrillar PHB scaffolds after 7 days of treatment. 


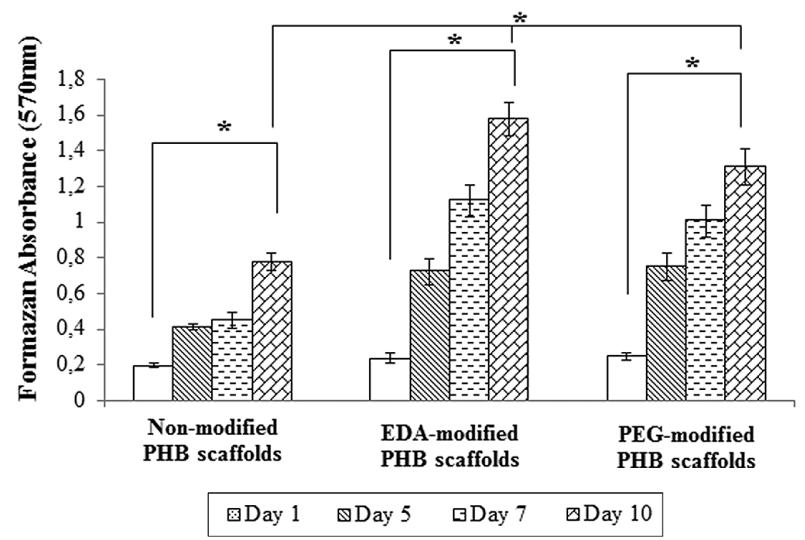

Figure 9. Cell attachment of mouse urinary bladder cells on nonmodified and modified PHB scaffolds for 10 days $(n=6)$. Cellular proliferation increased on EDA- and PEG-modified PHB scaffolds. Statistical significance $(p<0.005)$ are marked as *.

structured surface promotes cellular adhesion, proliferation, and regeneration because of the similarity to the natural extracellular matrix. Besides this cellular compatibility of nanomaterials, the investigation of nanotextured surface is important related to bladder stones formation and inhibition for bladder tissue engineering applications. For these reasons, the prepared bacterial PHB nanofibrilar scaffold was examined for the suitability to be used in bladder reconstruction. In order to produce PHB, A. eutrophus was grown under in the presence of excess carbon source and stepwise purification of PHB was performed, using sodium-hypochlorite and chloroform. A polymer crystallinity property of electrospun fibers was characterized using DSC. Figure 1 shows that almost same crystallinity can be found for both PHB by comparing crystallinity of its commercial counterparts (62\%) and bacterial PHB (59.7\%; Chaijamrus and Udpuay 2008). Therefore, it can be said that the bacterial PHB can be produced at a reproducible quality and was in the usual range of crystallinity value. Average molecular weight of bacterial PHB determined using viscosimetric measurement and has a molecular mass of 82,500 g/mol.

Figure 2 shows that is fibrous and highly porous electrospun fiber PHB scaffolds. The average size of fiber diameter was ranged from 700 to $800 \mathrm{~nm}$. Images were also taken using SEM for the visual analysis in order to assess of calcium oxalate crystal shape. The characteristic morphology and absorbtion bands of oxalate crystals are shown in Figures 3 and 4, respec- tively. However, it was found that the average size of these single crystals is $71.65 \mu \mathrm{m}$ in length and $23.74 \mu \mathrm{m}$ in width.

Water contact angle measurements on the non-modified and modified PHB scaffolds are shown in Figure 5. The average contact angle on the non-mofied PHB scaffold was $110.5 \pm 1.5^{\circ}$, which was higher than all of the modified scaffolds $(p<0.05)$. After plasma treatment, the contact angle significantly decreased and the lowest water contact angle $\left(23.6^{\circ}\right)$ was observed for EDAmodified scaffolds. The trend may be attributed to the effect of the change in surface chemistry, specifically the creation of amine groups on PHB nanofibrilar scaffolds. Mutlu et al. reported that the measured contact angles of the non-modified and quartz crystal surface modified with etylenediamine are $62 \pm 5$ and $23 \pm 4$, respectively (Mutlu et al. 2008). These results are compatible with the measured contact angles on the PHB scaffolds.

In this study, inhibition of the crystal growth is believed to be due to modification process because the presence of PEG and EDA inhibited the crystal growth of calcium oxalate due to the presence of functional groups.

MTT assay results are shown in Figure 9. Modified scaffolds exhibited greater cell growth than that of the modified PHB scaffolds. Comparing modified and nonmodified scaffolds, the formazan absorbance difference EDA- or PEG-modified scaffolds for became even more distinct $(p<0.005)$ at Day 10. The results indicate that plasmamodified scaffolds supported better the cell growth, especially EDA-modified scaffolds. Figure 10 shows uroepithelial morphology on a neat and modified PHB scaffods after 7 days. The bladder epithelial cells became elongated after 7 days of culture and especially, spread well on modified scaffolds. The SEM results suggest that bladder epithelial cells are able to grow and proliferate well on modified PHB scaffolds.

\section{Conclusions}

Based on the reported results, plasma modifications of scaffolds were performed successfully as can be seen from the results of contact angle experiment. According to Alizarin-red staining results, PEG- and EDA-modified scaffolds inhibited more crystal growth of calcium oxalate compared to non-modified scaffolds. Moreover, results of the cell proliferation experiments indicated that EDAplasma-modified PHB scaffolds enhanced the cell adhesion and proliferation compared to the non-modified and PEG-modified scaffolds. As a conclusion, this study
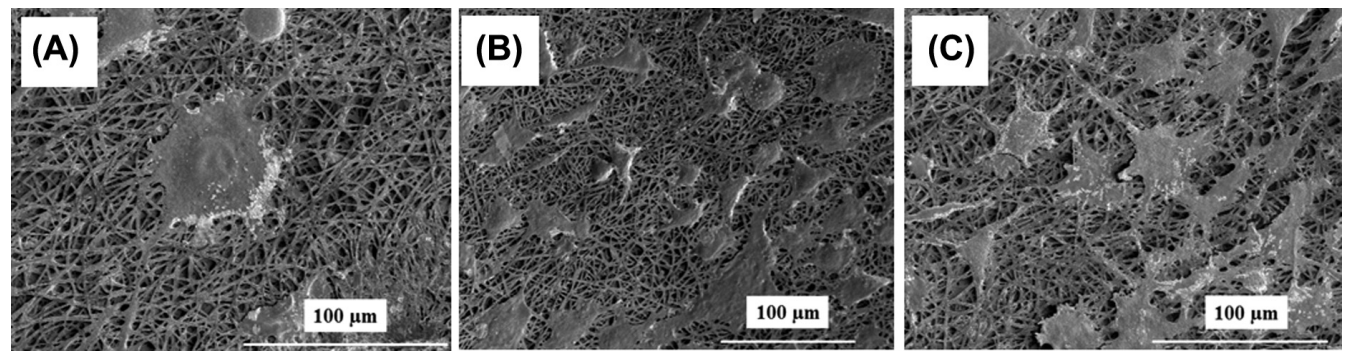

Figure 10. SEM images of mouse urinary bladder cells that were cultured on(A) non-modified, (B) EDA-modified and(C) PEG-modified nanofibrous PHB scaffolds for 7 days. Scale bars are $100 \mu \mathrm{m}$. 
demonstrated that plasma-modified nanotexture surface not only enhanced mouse urinary bladder cell adhesion and growth but also reduced the calcium oxalate stone formation. Therefore, the prepared modified PHB nanofiber scaffold is a promising candidate for long-term use in bladder tissue engineering applications.

\section{Acknowledgments}

This study was carried out under the auspices of the Hacettepe University, Scientific Researches Unit.

\section{Declaration of interest}

The authors report no declarations of interest. The authors alone are responsible for the content and writing of the paper.

\section{References}

Atala A. 2000. Tissue engineering for bladder substitution. World J Urol. 18:364-370.

Baker SC, Atkin N, Gunning PA, Granville N, Wilson K, Wilson D, Southgate J. 2006. Characterisation of electrospun polystyrene scaffolds for three-dimensional in vitro biological studies. Biomaterials. 27:3136.

Barham PJ, Keller A, Otun EL, Holmes PA. 1984. Crystallization and morphology of a bacterial thermoplastic: poly-3-hydroxybutyrate. J Mater Sci. 19:2781-2794.

Chaijamrus S, Udpuay N. 2008. Production and characterization of polyhydroxybutyrate from molasses and corn steep liquor produced by Bacillus megaterium ATCC 6748 . Agric Engg Int: CIGR Ejournal Manuscript FP 07 030. Vol. X.

Channa NA, Ghangro AB, Soomro AM, Noorani L. 2007. Analysis of kidney stones by FTIR spectroscopy. J Liaquat Uni Med Health Sci. 6:66-73.

Chen GQ, Wu Q. 2005. Polyhydroxyalkanoates as tissue engineering materials. Biomaterials. 26:6565-6578.

Chun YW, Khang D, Haberstroh KM, Webster TJ. 2009. The role of polymer nanosurface rougness and submicron pores in improving bladder urothelial cell density and inhibiting calcium oxalate stone formation. Nanotechnology. 20:085104.

Chun YW, Lim H, Webster TJ, Haberstroh KM. 2010. Nanostructured bladder tissue replacement. Wiley Interdiscip Rev Nanomed Nanobiotechnol. 3:134-145.

Cincu C, Butac LM, Iliescu M. 2000. Concentration critique des polymères dans des solutions très diluēes. Eur Polym J. 36:473-477.

Clarotti G, Schue F, Sledz J, Ait Ben Aoumar A, Geckeler KE, Orsetti A, Paleirac G. 1992. Modification of the biocompatible and haemocompatible properties of polymer substrates by plasma-deposited fluorocarbon coatings. Biomaterials. 13:832-840.

Demirbilek ME, Demirbilek M, Karahaliloğlu Z, Erdal E, Vural T, Yalçın E, et al. 2011. Oxidative stress parameters of L929 cells cultured on plasma-modified PDLLA scaffolds. Appl Biochem Biotechnol. 164:780-792.

Deng LQ. 2007. Regulation of polymer on calcium oxalate urinary calculi grown in aqueous solutions, Master Degree, pp. 12-28.

Eberli D. 2010. Tissue Engineering. Vienna, Austria: INTECH, p. 120.

Erceg M, Kovačić T, Klarić I. 2005. Thermal degradation of poly(3hydroxybutyrate) plasticized with acetyl tributyl citrate. Polym Degrad Stabil. 90:313-318.

García-García JM, López L, París R, Núñez-López MT, Quijada-Garrido I, De La Peña Zarzuelo E, Garrido L. 2012. Surface modification of poly(3-hydroxybutyrate-co-3-hydroxyvalerate) copolymer films for promoting interaction with bladder urothelial cells. J Biomed Mater Res A. 100:7-17.

Gogolewski S, Jovanovic M, Perren SM, Dillon JG, Hughes MK. 1993. Tissue response and in vivo degradation of selected polyhydroxyacids: polylactides (PLA), poly(3-hydroxybutyrate) (PHB), and poly(3-hydroxybutyrate-co-3-hydroxyvalerate) (PHB/VA). J Biomed Mater Res. 27:1135-1148.

Harrington DA, Cheng EY, Guler MO, Lee LK, Donovan JL, Claussen RC, Stupp SI. 2006. Branched peptide-amphiphiles as self-assembling coatings for tissue engineering scaffolds. J Biomed Mater Res A. 78:157-167.

Harrington DA, Sharma AK, Erickson BA, Cheng EY. 2008. Bladder tissue engineering through nanotechnology. World J Urol. 26:315-322.

Ichikawa F, Kobayashi M, Ohta M, Yoshida Y, Obuchi S, Itoh H. 1995. U.S. Patent 5,440,008.

Karahaliloğlu Z, Demirbilek M, Şam M, Erol-Demirbilek M, Sağlam N, Denkbaş EB. 2012. Plasma polymerization-modified bacterial polyhydroxybutyrate nanofibrillar scaffolds. J. Appl Polym Sci. 128:1904-1912.

Khang D, Kim SY, Liu-Synder P, Palmore GTR, Durbin SM, Webster TJ. 2007. Enhanced fibronectin adsorbtion on carbon nanotube/poly(carbonate) urethane: independent role of surface nanorougness and associated surface energy. Biomaterials. 28:4756-4768.

Langer R, Vacanti JP. 1993. Tissue engineering. Science. 260:920-926.

Lee SY. 1996. Bacterial polyhydroxyalkanoates. Biotechnol Bioeng. 49: $1-14$.

Lenz RW, Marchessault RH. 2005. Bacterial polyesters: biosynthesis, biodegradable plastics and biotechnology. Biomacromolecules. 6:1-8.

Li J, Zhu B, Y. He Y, Inoue Y. 2003. Thermal and Infrared Spectroscopic Studies on Hydrogen-Bonding Interaction between Poly(3-hydroxybutyrate) and Catechin. Polym J. 35:384-392.

Li WJ, Laurencin CT, Caterson EJ, Tuan RS, Ko FK. 2002. Electrospun nanofibrous structure: a novel scaffold for tissue engineering. J Biomed Mater Res. 60:613-621.

Mikos AG, Thorsen AJ, Czerwonka LA, Bao Y, Langer R. 1994. Preparation and characterization of poly(l-lactic acid) foams. Polymer. 35:1069-1077.

Miller DC, Haberstroh KM, Webster TJ. 2005. Mechanism (s) of increased vascular cell adhesion on nanostructured poly(lactic-coglycolic acid) films. J Biomed Mater Res A. 73:476-484.

Mooney DJ, Baldwin DF, Suh NP, Vacanti JP, Langer R. 1996. Novel approach to fabricate porous sponges of poly(d,l-lacticco-glycolic acid) without the use of organic solvents. Biomaterials. 17:1417-1422.

Mutlu S, Çökeliler D, Shard A, Goktas H, Ozansoy B, Mutlu M. 2008. Preparation and characterization of ethylenediamine and cysteamine plasma polymerized films on piezoelectric quartz crystal surfaces for a biosensor. Thin Solid Films. 516: 1249-1255.

Ouyang JM, Deng SP. 2003. Controlled and uncontrolled crystallization of calcium oxalate monohydrate in the presence of citric acid. Dalton Trans. 14:2846-2851.

Pathak P, Naik PK, Sengupta D, Singh SK, Tandon C. 2011. Mode of interaction of calcium oxalate crystal with human phosphate cytidylyltransferase 1: a novel inhibitor purified from human renal stone matrix. J. Biomed Sci Eng. 4:591-598.

Pattison MA, Wurster S, Webster TJ, Haberstroh KM. 2005. Three-dimensional, nano-structured PLGA scaffolds for bladder tissue replacement applications. Biomaterials. 26:2491-2500.

Persidis A. 1999. Tissue engineering. Nat Biotechnol. 17:508-510.

Ratner BD, Hoffman AS, Schoen FJ, Lemons JE, Eds. 2004. Biomaterials science: An Introduction to Materials in Medicine. Elsevier: Amsterdam, pp. 218.

Renard E, Vergnol G, Langlois V. 2011. Adhesion and proliferation of human bladder RT112 cells on functionalized polyesters. IRBM. 32:214-220.

Silverstein RM, Webster FX, Kiemle DJ. 2005. Infrared spectroscopy. In: Bennon D, Yee J, Eds. Spectrometric Identification of Organic Compounds, 7th ed. New York, John Wiley and Sons, Inc., pp. $72-126$.

Sombatmankhong K, Sanchavanakit N, Pavasant P, Supaphol P. 2007. Bone scaffolds from electrospun fiber mats of poly(3-hydroxybutyrate), poly(3-hydroxybutyrate-co-3-hydroxyvalerate) and their blend. Polymer. 48:1419-1427.

Yehia NS, Essa FA, Shalaby NY. 2012. Kinetics of dissolution of calcium oxalate monohydrate crystals as being influenced by some organic compounds. World J Chem. 7:17-21.

Zhang D, Qi L, Ma J, Cheng H. 2002. Morphological Control of Calcium Oxalate Dihydrate by a Double-Hydrophilic Block Copolymer. Chem Mater. 14:2450-2457.

Zhang Y, Kropp BP, Lin HK, Cowan R, Cheng EY. 2004. Bladder regeneration with cell-seeded small intestinal submucosa. Tissue Eng. 10:181-187.

Zhang YY, Kropp BP, Moore P, Cowan R, Furness PD III, Kolligian ME, et al. 2000. Co-culture of bladder urothelial and smooth muscle cells on small intestinal submucosa (SIS): Potential applications for tissue engineering technology. J Urol. 164:928. 